\title{
PILIHAN METODE MANAJEMEN PROYEK DAN PENGEMBANGAN APLIKASI PADA PERUSAHAAN PEMULA PENGEMBANG PERANGKAT LUNAK DI JAKARTA
}

\author{
Hudiarto \\ Information Systems Department, School of Information Systems, Binus University \\ Jl. K.H. Syahdan No. 9, Palmerah, Jakarta Barat 11480 \\ hudiarto@binus.edu
}

\begin{abstract}
The ability of Indonesian computer practitioners in making business applications programs which are both internet-based and non-internet-based is already satisfactory. Their work can be viewed from a variety of business applications commissioned by many local, national and international levels. The problem often encountered is the lack of project management at the company maker of project business applications. It may affect the availability of adequate documentation as part of the project output. In this paper the author recommends software developing using a concept by McConnell (1996) that depends on the project's characteristics and scope. McConnell is one of the mainstays of Microsoft experts who experiences many years as a project leader software made by the company. The object of this paper is to study several beginner companies of software developer in Jakarta. The software coverage is especially for profit company and both internet-based and non internet-based applications. From a comparison of several projects it is found that that late delivery often occur since the methid is implemented less stringent. This study is expected to be useful for other novice developers who get difficulty in submission software on time, right cost and right quality at the scope of the software that has been agreed.
\end{abstract}

Keywords: project management, business software, software development method

\begin{abstract}
ABSTRAK
Kemampuan praktisi komputer Indonesia dalam membuat program aplikasi bisnis yang berbasis internet maupun yang tidak sudah cukup memadai. Hasil karya mereka bisa dilihat dari berbagai aplikasi bisnis yang dipesan oleh banyak perusahaan lokal, nasional maupun internasional. Masalah yang sering ditemui adalah lemahnya manajemen proyek saat perusahaan mengerjakan proyek aplikasi bisnis ini. Hal itu sedikit banyak akan mempengaruhi ketersediaan dokumentasi yang layak sebagai bagian dari serahan proyek tersebut. Dalam makalah ini penulis merekomendasikan agar pengembang perangkat lunak menggunakan konsep yang dibahas oleh McConnell (1996) karena ia adalah salah satu pakar andalan Microsoft dan berpengalaman puluhan tahun sebagai pimpinan proyek perangkat lunak yang dibuat oleh perusahaan itu. Obyek penelitian pada makalah ini adalah beberapa perusahaan pemula pengembang perangkat lunak di Jakarta. Cakupan perangkat lunak terutama adalah untuk perusahaan yang mencari laba dan aplikasinya yang berbasis internet maupun yang tidak. Metodologi yang dipakai mengikuti apa yang disarankan oleh McConnell yaitu tergantung dari sifat dan besar-kecilnya proyek tersebut. Dari perbandingan beberapa proyek didapat bahwa seringkali keterlambatan penyerahan terjadi karena kurang ketatnya metode tersebut dijalankan. Diharapkan juga dapat bermanfaat bagi pengembang pemula lainnya yang mendapatkan kesukaran dalam penyerahan perangkat lunak yang tepat waktu, tepat biaya dan tepat kualitas pada ruang lingkup perangkat lunak yang telah disepakati bersama.
\end{abstract}

Kata kunci: manajemen proyek, perangkat lunak bisnis, metode pengembangan 


\section{PENDAHULUAN}

Jakarta, Bandung, Yogyakarta, Surabaya adalah sebagian kota-kota besar di Indonesia yang memiliki puluhan pengembang perangkat lunak baik yang berskala besar, menegah maupun kecil. Banyak dari perusahaan ini dimiliki oleh para wira usaha muda yang kebanyakan berlatar pendidikan teknologi informasi atau punya minat di bidang itu. Dengan latar belakang seperti itu ditambah dengan adanya modal yang cukup dari penyandang dana, mereka mulai berani untuk mengembangkan proyek perangkat lunak bisnis yang perangkat lunak tadi menjadi inti kekuatan proses bisnis perusahaan.

Proyek menurut Project Management Institute (2008) adalah suatu usaha dalam waktu tertentu (sementara) yang diambil untuk menciptakan produk atau jasa yang unik. Proyek memiliki awal dan akhir yang jelas. Proyek dilaksanakan pada semua level organisasi. Proyek bisa melibatkan satu atau ribuan orang, satu unit tunggal dari suatu organisasi atau pun antar unit dari organisasi yang berbeda. sementara Manajemen proyek menurut Project Management Institute (2008) adalah penerapan dari pengetahuan, keahlian, alat-alat (tool) dan teknik pada aktivitas proyek guna memenuhi atau mencapai kebutuhan dan harapan stakeholder dari suatu proyek.

Banyaknya jenis usaha dan rincian proses bisnis yang tidak seragam untuk satu jenis usaha yang sama dapat menimbulkan masalah bagi analis dan pemrogram senior untuk dapat memahami proses bisnis secara tuntas. Selain itu manajemen proyek yang baik ternyata belum banyak dilakukan oleh para pengembang tersebut sehingga tingkat kematangan pengembang belum bisa beranjak naik ke tingkat kematangan tertentu seperti yang disarankan pada capability maturity model. Bila dilihat dari pengalaman di India, di mana untuk tahun '80an belum terlihat adanya penggunaan dan pengembangan aplikasi komputer secara masif tetapi dalam kurun waktu 20 tahun India sudah mampu membuat perangkat lunak berkualitas dunia. Meskipun perusahaan mereka sederhana tetapi karena ketatnya mereka memegang prinsip manajemen proyek, khususnya di bidang perangkat lunak, maka dengan cepat mereka bisa memperoleh kepercayaan perusahaan pengembang kelas dunia seperti Microsoft, Computer Assosiate, Apple. Begitu pula dengan perusahaan China yang baru tahun 2000'an berkolaborasi dengan perusahaan Amerika Serikat dengan cepat merebut kepercayaan itu dan mulai bersaing dengan perusahaan India.

Banyak pengembang perangkat lunak di Indonesia yang dimulai dari kecil dan biasa disebut dengan software house. Karena masih kecil dan ingin eksis dengan cepat, target pekerjaaan mereka adalah dapat selesai tepat waktu, dana yang dikeluarkan memadai dalam arti mereka masih dapat untung, namun kualitas sering dikorbankan karena kurang memiliki pengetahuan dalam manajemen proyek. Pada umumnya perusahaan pengembang kelas pemula ini menggunakan metode Code and Fix. Metode ini bisa saja digunakan untuk proyek berskala kecil dan tidak beresiko tinggi. Untuk proyek pengembangan aplikasi yang berskala menengah yang sudah mengandung kompleksitas dan resiko yang cukup tinggi maka metode lain perlu diperhatikan.

Mengelola pengembangan perangkat lunak berbeda sekali dengan mengelola proyek di pabrik atau bangunan sipil. Pada proyek pengembangan perangkat lunak perlu memperhatikan banyak sekali aspek yang terkait secara langsung maupun tidak langsung. Justru saat pengembang masih pemula perlu dibekali dengan pengetahuan yang cukup tentang manajemen perangkat lunak yang memadai. Harapannya adalah agar para pengembang pemula ini dapat cepat tumbuh menjadi menengah bahkan besar seperti perusahaan yang ada di India maupun China.

Seperti yang telah disinggung diatas, masalah akan terkait dengan penentuan ruang lingkup proyek yang pada umumnya agak berubah dari waktu ke waktu, dana yang sebenarnya terlalu kecil karena pengembang perlu melakukan pelatihan bagi analis dan pemrogramnya selain pembelian perangkat lunak berlisensi yang cenderung naik dari tahun ke tahun, waktu pengerjaan yang terlalu 
sempit karena pemilik proyek cenderung ingin cepat menggunakan perangkat lunak itu, dan kualitas perangkat lunak yang tidak konsisten dari modul yang satu dengan modul lainnya. Makalah ini difokuskan pada pengembang pemula yang banyak sekali menghadapi berbagai tantangan yang perlu diatasi. Beberapa masalah yang perlu difokuskan dan segera harus dapat diatasi, antara lain: (1) bagaimana mengatasi masalah perubahan kebutuhan user yang sering terjadi dalam pengelolaan proyek?; (2) bagaimana mengelola beberapa proyek pada saat yang hampir bersamaan dengan sumber daya yang tersedia dan terbatas?; (3) model pengelolaan apa yang tepat untuk digunakan untuk mengelola proyek-proyek tersebut supaya dapat selesai tepat waktu dan memenuhi kebutuhan user?

Tujuan dituliskannya makalah ini adalah sebagai berikut: (1) pengembang mampu memberikan ketegasan dalam menetapkan ruang lingkup agar tidak berubah dari waktu ke waktu, memberikan usulan penjadwalan yang masuk akal untuk membantu pengelolaan proyek-proyek tersebut dan mengurangi masalah yang mungkin terjadi karena terjadinya perubahan ruang lingkup; (2) perusahaan memiliki kemampuan mengelola beberapa proyek sekaligus dalam waktu yang bersamaan, mulai dari tahap definition sampai tahap operation (proyek siap untuk serah terima) dengan baik; (3) perusahaan mampu untuk mengelola proyek-proyek tersebut, seperti estimasi jadwal, sumber daya, dan kehabisan dana sebelum proyek diserahkan dan kualitas yang memadai.

Adapun manfaat dari penelitian ini yaitu: (1) tim proyek dapat menjalin hubungan yang lebih baik dengan client atau user sehingga proyek dapat memenuhi kebutuhan yang diharapkan karena ruang lingkup yang tidak berubah banyak; (2) pengelolaan setiap proyek dapat berjalan sesuai rencana penjadwalan; (3) masalah yang timbul atas proyek dapat ditekan seminimal mungkin; (4) memberikan kontribusi berarti bagi perkembangan bidang ilmu manajemen, khususnya ilmu manajemen proyek perangkat lunak, dalam hal pemanfaatan teknologi informasi yang lebih tepat guna dan pengembangan perangkatlunak yang selaras dengan kebutuhan dunia usaha.

\section{METODE}

Menurut Rakos (1990), terdapat tujuh tahapan dalam manajemen proyek perangkat lunak, yaitu: definition, analysis, design, programming, system test, acceptance, dan operation. Pada dasarnya dengan tujuh tahapan ini apabila pengembang aplikasi mengikuti dengan baik setiap tahapannya maka akan banyak terhindar dari berbagai kesulitan di kemudian hari. Pemahaman yang mendalam akan tahapan ini boleh dikatakan mutlak diperlukan. Kekurangtahuan atau mengabaikan apa yang seharusnya dilakukan saat mengembangkan aplikasi bisnis akan menyebabkan jadwal penyerahan menjadi mundur, biaya pengembangan menaik dan sebagai konsekuensinya adalah proyek menjadi rugi.

\section{Model Pengembangan}

Terdapat banyak model pengembangan yang ada dan sudah ditulis di banyak buku, namun pada makalah ini hanya dibahas beberapa model yang diperkirakan sesuai digunakan.

\section{Waterfall Model}

Menurut Olson (2004, p 127), Waterfall Model menggunakan loop umpan balik antara tahapan-tahapan dari pengembangan perangkatlunak untuk meminimalisasi kerja ulang (rework). Model ini dinamakan waterfall karena setiap langkahnya mengikuti predecessor (aktivitas yang harus dilaksanakan sebelum aktivitas yang mengikutinya dimulai) secara berurutan. Waterfall Model tidak memungkinkan respon yang cepat pada penyelesaian perubahan dalam proyek. Urutan aktifitas yang teratur pada Waterfall Model tidak mengakomodasi pengembangan baru. 


\section{Staged Delivery}

Menurut McConnell (1996, p 549-558), staged delivery adalah suatu model siklus hidup di mana perangkatlunak dikembangkan dalam tahapan-tahapan dan dapat meningkatkan keseluruhan kualitas kode, mengurangi resiko pembatalan proyek dan mendukung usaha membangun anggaran. Keuntungan utama dari model ini adalah memungkinkan tim proyek untuk menyerahkan fungsionalitas yang berguna ke klien lebih awal dari pada jika tim proyek menyerahkan 100\% proyek pada akhir proyek. Model ini juga menyediakan tanda-tanda kemajuan proyek yang dapat diukur lebih awal dari pada pendekatan yang kurang incremental. Tanda kemajuan seperti itu dapat menjadi sesuatu yang berharga dalam menjaga tekanan jadwal pada tingkat manajerial.

\section{Metode Perencanaan}

Menurut Shelford dan Remillard (2003, p 107), perencanaan membutuhkan langkah-langkah berikut yang harus diambil oleh project manager sebagai tanggung jawab utamanya, yaitu: mengembangkan suatu work breakdown structure (WBS) dengan mengidentifikasi tahapan dan aktvitas proyek, mengidentifikasi ketergantungan antar aktivitas dan memberikan highlight pada jadwal dengan menggunakan warna atau notasi khusus, mengidentifikasi aktivitas yang dapat berjalan bersamaan atau secara paralel, mengestimasi usaha dan durasi dari masing-masing proyek dengan berkonsultasi dengan anggota tim, membuat draft jadwal proyek dan menganalisa hasilnya, memperoleh persetujuan (approval), menugaskan resource, dan menjadwalkan penugasan kerja.

\section{Joint Application Development (JAD)}

Menurut McConnell (1996, p 449-462) Joint Application Development (JAD) adalah metodologi requirements definition dan desain user interface di mana end-user, pihak manajemen, dan developer menghadiri pertemuan secara intensif untuk mengumpulkan rincian sistem. JAD lebih fokus pada masalah bisnis daripada rincian teknis. Keberhasilan JAD tergantung pada kepemimpinan yang efektif dari sesi JAD, partisipasi end-user utama, pihak manajemen, developer, dan pencapaian sinergi kelompok selama sesi JAD.

\section{Metode Penjadwalan}

Menurut Olson (2004, p 173), Critical Path Method (CPM) adalah metodologi penjadwalan proyek untuk menentukan jadwal aktivitas yang optimal dengan memperhatikan waktu. CPM menyediakan dasar untuk mengidentifikasikan aktivitas-aktivitas khusus yang kritis dan membantu menentukan aktivitas-aktivitas mana yang dapat ditunda dalam kondisi resource yang terbatas. Aktivitas yang memiliki nilai slack sama dengan nol (0) disebut aktivitas kritis yang kemudian akan membentuk jalur kritis.

\section{Critical Success Factors (CSF)}

Menurut Olson (2004, p 10-13), faktor sukses yang kritis (Critical Success Factors) adalah suatu hal yang harus dilaksanakan dengan baik supaya aktivitas-aktivitas secara keseluruhan dapat berhasil diselesaikan. Menurut McConnell (1996, p 40-49), terdapat kesalahan-kesalahan klasik yang berhubungan dengan empat dimensi pengembangan perangkatlunak, yaitu orang, proses, produk dan teknologi.

\section{Internet dan Web}

Menurut Schwalbe (2010), internet adalah nama sebuah sistem yang sangat luas, mencakup seluruh dunia yang terdiri dari orang-orang, informasi, dan komputer. Internet adalah sebuah istilah 
untuk sistem world-wide yang sangat luas. Sistem tersebut terdiri dari berjuta-juta jaringan komputer yang dapat dihubungkan dengan kabel, saluran telepon, sambungan satelit, dan sebagainya yang keseluruhan alat itu bertujuan untuk menghubungkan antara client dan server supaya dapat berkomunikasi satu dengan yang lainnya. Menurut Schwalbe selanjutnya world wide web atau biasa disebut web adalah suatu sistem server yang besar dan mengatur berbagai macam informasi yang dapat berupa teks, gambar maupun suara.

\section{Pengendalian Proyek Perangkat Lunak}

Menurut Rakos (1990, p 235-244), pengendalian dapat dilakukan dengan menggunakan rapat tatap muka atau pertemuan (meeting), tinjauan ulang (review), maupun laporan (report). Pada umumnya pengendalian dilakukan terutama secara internal di perusahaan pengembang setelah itu dilakukan dengan presentasi dihadapan pemilik proyek atau klien untuk mendapat masukan.

\section{HASIL DAN PEMBAHASAN}

\section{Pelaksanaan Proyek Pengembangan dan Masalah yang Dihadapi}

Beberapa perusahaan pengembang pemula dan menengah perangkat lunak diamati secara dekat dalam kurun waktu yang cukup lama, sekitar dua tahun, untuk mendapatkan gambaran lengkap proses pelaksanaan pengembangan dan aplikasi yang dibuat adalah untuk kepentingan bisnis yang mencari laba. Perusahaan perusahaan ini memiliki keterbatasan yang hampir sama, yaitu minimnya sumber daya manusia yang punya keahlian dan keterampilan seperti yang diminta pada proyek, dana dan pengalaman yang terbatas dalam mengelola proyek. Namun ada kelebihan yang mereka punyai yaitu mempunyai relasi yang banyak sebagai calon klien yang percaya bahwa para pengembang ini dapat membantu untuk menyediakan perangkat lunak yang mereka butuhkan.

\section{Gambaran Umum Proyek Perangkat Lunak yang Ditangani}

\section{Proyek Aplikasi Agribisnis}

Proyek ini tergolong proyek kecil karena tingkat kompleksitas yang rendah dan resiko yang kecil. Aplikasi ini bersifat informatif dengan berorientasi pada para pengguna sebagai end user. Pada aplikasi ini ditampilkan informasi mengenai buah-buahan, sayur-sayuran, dan tanaman hias. Organisasi agribisnis yang menjadi klien ini merupakan suatu badan yang bernaung di bawah sebuah Kementerian. Pada aplikasi yang terdahulu informasi hanya dapat diakses apabila para pengguna sudah masuk lebih dulu ke situs induk yang dibuat oleh kementerian itu. Hal itu dimaksudkan agar aplikasi tidak tercerai berai dan berkembang tanpa kendali. Selain itu dengan aplikasi ini para pengguna dapat berkomunikasi satu sama lainnya sehingga meningkatkan kemampuan untuk berbagi diantara sesama pengguna. Diharapkan aplikasi ini adalah sebagai cikal bakalnya intranet pada unit organisasi ini.

\section{Proyek Portal Asuransi}

Proyek aplikasi terkait portal asuransi dimaksudkan agar semua calon nasabah maunpun yang sudah menjadi nasabah dengan mudah dapat data dan informasi apa saja yang ada kaitannya dengan asuransi yang ada di Indonesia. Dengan demikian para nasabah mampu membandingkan besarnya premi dan manfaat yang bisa dia peroleh dari setiap perusahaan asuransi. Para agen penjual premi asuransi biasanya sangat pandai membujuk sehingga banyak para nasabah memandang bahwa perusahaan asuransi tidaklah lebih dari perusahaan yang kurang bisa dipercaya. Bukannya 
mendapatkan perlindungan yang dibutuhkan malahan para nasabah mendapatkan kesulitan tambahan yang tidak perlu karena harus berhubungan dengan perusahaan asuransi. Sistem aplikasi ini sudah dibuat oleh peusahaan asing dan dipasang pada sebuah super mini computer. Mengingat biaya perawatan komputer ini makin lama dirasakan makin mahal maka perlu dipindahkan dengan melakukan Business Process Reengineering. Apilkasi baru itu kemudian dipindahkan ke beberapa blade server dan ditingkatkan kinerja maupun fiturnya.

\section{Proyek HPS}

Proyek ini dikembangkan untuk menggantikan aplikasi yang lama dan dapat diakses lewat suatu situs tertentu. Aplikasi ini akan digunakan oleh semua para pemangku kepentingan (stakeholder) dari suatu organisasi. Aplikasi yang lama mengandung informasi yang kurang detil mengenai profil dan produk dari HPS. Sedangkan aplikasi baru menampilkan informasi rinci mengenai setiap level pada kegiatan unit usaha. Akan tetapi, informasi yang ditampilkan tidak termasuk rincian biaya karena pihak HPS mengharapkan pemangku kepentingan dapat menghubungi atau mendatangi pihak HPS secara langsung sehingga informasi tersebut dapat sampai kepada pemangku kepentingan yang tepat.

\section{Proyek IM}

Proyek ini memiliki tingkat kompleksitas yang lebih tinggi dibandingkan proyek proyek yang lain. Hal ini dilihat dari jumlah orang dan ragam keahlian yang terlibat. Proyek ini tidak hanya bersifat informatif, tetapi juga terdapat tampilan Flash yang menarik yang menggambarkan keunggulan produk yang dijual, serta Community yang berbasis web. Ada perhitungan dan komparasi untuk memilih produk sejenis dari perusahaan lain termasuk kemungkinan membeli dengan berbagai tingkat uang muka dan angsuran pinjaman per bulannya sehingga mirip dengan system pendukung keputusan.

\section{Proyek Sediaan Kabel pada Distributor Tunggal}

Proyek bangunan perkantoran baik ruko, gedung berlantai banyak, kompleks perumahan, apartemen maupun Mall yang banyak menjamur di ibu kota dan sekitarnya tidak terlepas dengan kebutuhan kabel listrik dengan berbagai jenis dan jumlahnya. Sebagai distributor tunggal, perusahaan ini banyak menerima pesanan dari para kontraktor yang memesan berbagai jenis kabel sesuai dengan rencana awal rancangan sipil yang akan dibangun. Distributor yang terkenal dengan memberikan harga murah ini kemudian melakukan pemesanan kepada pabrik. Namun seperti biasa, sering terjadi perubahan spesifikasi rancangan sipil tersebut sehingga ikut merubah spesifikasi kabel yang dibutuhkan. Yang lebih parah adalah beberapa jenis kabel yang telah dipotong sesuai dengan pesanan kontraktor, sebelum dikirim ternyata dibatalkan. Masalahnya adalah bagaimana memberikan beban biaya yang wajar atas pembatalan ini dan penempatan barang yang sudah dipotong ini dengan baik. Bila tidak disimpan dengan baik maka harga kabel potongan ini, meskipun baru, bisa tidak laku dijual dan hanya bisa dijual dengan harga murah. Jelas praktek semacam ini menimbulkan kerugian.

\section{Analisis Tahapan Pengelolaan Proyek Perangkat Lunak}

Tahapan pengelolaan proyek yang berjalan di perusahaan-perusahaan pengembang tadi adalah sama yaitu dengan melalui kegiatan requirement gathering/design, development, testing, deployment, dan warranty period. Lima tahapan ini berjalan setelah melewati alur inisiasi yang memberikan hasil bahwa suatu proyek dinyatakan approved untuk dijalankan. Model siklus hidup yang digunakan untuk perencanaan proyek web di perusahan-perusahan tadi kebanyakan adalah waterfall model yang fleksibel dan iteratif untuk kembali ke tahap sebelumnya. Bila dibandingkan dengan metode yang disarankan Rakos, jelas masih ada kekurangan. Alasan mereka untuk tidak sepenuhnya mengikuti 
metode itu karena tujuan mereka dapat segera terpenuhi yaitu menyerahkan hasil tepat waktu, meskipun ternyata mundur dari batas waktunya.

\section{Analisis Struktur Organisasi Tim Proyek}

Dilihat dari otoritas dan tanggung jawab dari manajer fungsional dan manajer proyek (PM), struktur organisasi yang digunakan kebanyakan adalah matriks karena dinilai dapat untuk meningkatkan efektifitas dan efisiensi sumber daya manusia yang terbatas. Penggunaan struktur organisasi matriks pada pembuatan proyek perangkat lunak akan dapat mengoptimalkan jadwal proyek.

Beberapa permasalahan yang sering terjadi dalam pelaksanaan dan mengelola proyek perangkat lunak ini adalah sebagai berikut: (1) kesulitan pihak analis (ataupun nama lain yang dipakai oleh masing-masing perusahaan pengembang) untuk menemui nara sumber yang berkepentingan dengan proses bisnis yang sedang dikembangkan; (2) office politics di lingkungan klien atau narasumber, di mana perangkat lunak yang dikembangkan sudah tepat tetapi tidak mendapatkan persetujuan dari pihak yang memiliki wewenang lebih tinggi; (3) kecenderungan actual schedule bisa jauh melampaui baseline schedule yang sudah direncanakan semula. Hal ini dapat terjadi karena nara sumber sering melakukan perubahan terhadap kebutuhan user (user requirements).

\section{Analisis Pengendalian Proyek Perangkat Lunak}

Pengembang melakukan pengendalian terhadap proyek perangkat lunak dengan kegiatan pertemuan (meeting) dan pelaporan (reporting). Pengendalian ini dilakukan baik secara internal (melibatkan pihak-pihak di dalam perusahaan ) maupun eksternal (melibatkan pihak klien).

Pelaporan internal dilakukan oleh project manager dalam beberapa bentuk yaitu: (1) project review, dibuat setelah tahapan deployment selesai. Isinya meliputi: Lesson Learned dan Performance of Project Team; (2) resource usage form, dibuat seminggu sekali dan berisi mengenai pemakaian resource dan rencana pemakaian resource di minggu berikutnya. Pelaporan ini dibuat secara manual; (3) actual work, dibuat dua minggu sekali untuk dilaporkan ke operation manager dan berisi aktualisasi dari jadwal baseline. Pelaporan eksternal dilakukan dalam bentuk progress report kepada pihak klien dua minggu sekali. Isinya meliputi tanggal terakhir update web site, update web site selanjutnya, persentase tahapan development yang telah dilaksanakan dan remaining tasks, isu-isu teknis dan non-teknis.

\section{Evaluasi Umum Pengelolaan Proyek yang Ditangani}

\section{Perencanaan Proyek}

Proyek-proyek yang telah dilakukan seperti yang dijelaskan di atas, sudah melakukan perencanaan dengan cara memperinci kegiatan proyek utuh menjadi kegiatan proyek yang diperkecil dan metode ini dikenal dengan nama Work Breakdown Structure (WBS). Melalui WBS ini semua anggota tim proyek mengetahui semua aktivitas yang harus diselesaikan untuk mencapai serahan proyek. Dengan penggunaan Waterfall Model, dapat dilihat bahwa klien cenderung dapat meminta perubahan atau revisi berkali-kali. Pada akhirnya semua proyek cenderung tidak selesai tepat pada waktu yang sudah direncanakan sebelumnya meskipun pengembang pada umumnya menggunakan perencanaan proyek melalui Microsoft Project.

\section{Penjadwalan Proyek}

Perusahaan pengembang perangkat lunak telah memanfaatkan Microsoft Project 2003 untuk mengelola proyek perangkat lunak. Dengan menggunakan tool ini, tim proyek dapat mengatur 
penjadwalan dan memantau perkembangan aktivitas proyek melalui menu Gantt Chart. Akan tetapi tool ini belum dimanfaatkan sepenuhnya seperti untuk menentukan jalur kritis dari proyek-proyek. Pada tool ini terdapat menu Project-Filtered for-Critical atau melalui menu Project-Group byCritical untuk mengetahui jalur aktivitas apa yang kritis.

\section{Pengendalian Proyek}

Perusahaan pengembang perangkat lunak telah melakukan pengendalian terhadap proyek perangkatlunak berbasis web dengan mengadakan pertemuan (meeting) dan pelaporan (reporting). Dalam setiap pertemuan yang diadakan, project manager memberikan pelaporan kemajuan proyek yang ditangani. Pelaporan ini dibuat baik secara lisan maupun tulisan oleh project manager dengan format masing-masing (belum distandarisasikan), dan bahkan melalui email. Saat ini pembuatan laporan di Perusahaan pengembang perangkat lunak belum menggunakan fasilitas yang tersedia dalam Microsoft Project.

\section{Pengelolaan Proyek yang Ditangani}

Evaluasi khusus meliputi Work Breakdown Structure (WBS), milestones, aktivitas-aktivitas yang mengalami kemunduran serta hal yang menyebabkan kemunduran aktivitas dalam masingmasing proyek. Kurang fahamnya dalam memerinci proyek menjadi bagian yang lebih kecil sedemikian rupa agar tugas terkecil dapat dikerjakan dengan terkendali secara baik. Rumitnya proses bisnis bisa jadi penyebab. Untuk memahami lika liku proses bisnis memang perlu pengalaman dan butuh waktu, tidak sekedar dengan membaca atau mendengar cerita dari yang lebih senior.

\section{Usulan Mengelola Proyek Perangkat Lunak Agar Lebih Baik}

\section{Penerapan metode Staged Delivery}

Melalui penerapan metode Staged delivery, tim proyek dapat menyerahkan fungsionalitas yang berguna kepada klien lebih awal tanpa harus menunggu sampai proyek selesai $100 \%$. Hal ini memberikan manfaat bagi klien untuk melihat kemajuan proyek secara nyata dan dapat mulai menggunakan hasil proyek walaupun belum $100 \%$.

\section{Pemanfaatan metode Critical Path Method (CPM)}

Dilihat dari model siklus staged delivery yang berfungsi dengan baik apabila terdapat perencanaan yang seksama maka penerapan staged delivery perlu didukung dengan CPM. CPM dapat membantu menyediakan tanda-tanda kemajuan proyek dengan pengembangan jadwal terhadap aktivitas tertentu yang tergolong aktivitas kritis. Dengan mengetahui aktivitas mana saja yang kritis maka project manager dapat memperhatikan pelaksanaan dan kemajuan dari aktivitas kritis itu. Jika aktivitas kritis mengalami kemunduran maka jadwal pengembangan proyek secara keseluruhan akan mengalami kemunduran pula. Dalam hal ini, CPM perlu didukung dengan WBS yang sudah dibuat sebelumnya. CPM juga dapat membantu masalah teknis dalam perencanaan yang seksama.

\section{Penerapan Metode Joint Application Development (JAD)}

Penerapan JAD dilakukan pada tahapan Requirement Gathering/Design. Pertama, fase perencanaan (planning) terdiri dari tiga komponen sebagai berikut: (1) customization, meliputi: penentuan peserta JAD planning (JAD leader, project manager, business consultant, manager dari klien, PM/Kepala IT dari klien, perwakilan end user/web admin, dan notulis/scribe), penentuan tanggal sesi JAD planning, dan penyiapan material berupa contoh fitur web yang ada; (2) session, meliputi: pembahasan kebutuhan klien, pembatasan cakupan aplikasi web (fitur-fitur yang 
dibutuhkan), perkiraan fase perancangan JAD, penentuan dan penekanan content material yang diperlukan, penentuan tanggal fase perancangan JAD. pembahasan isu dan pertimbangan dalam proyek web, dan penyimpulan sesi; (3) wrap Up, memberikan hasil berupa: objektif dari aplikasi web, fungsi-fungsi aplikasi web, cakupan aplikasi web, batasan cakupan aplikasi web, daftar interface ke fitur atau menu lain, daftar isu yang berhubungan dengan aplikasi, dan rencana tahapan berikutnya.

Kedua, fase perancangan (design) juga terdiri dari tiga komponen yang sama dengan fase perencanaan, tetapi pada fase ini lebih berfokus pada kebutuhan perancangan user interface. Tiga komponen tersebut adalah: (1) customization, meliputi: penentuan peserta JAD Design (JAD Leader, project manager, business consultant, PM/Kepala IT dari klien, perwakilan end user/web admin, graphic designer, software developer, multimedia staff (jika perlu), dan notulis/scribe), penentuan tanggal sesi JAD Design, dan penyiapan material berupa template rancangan web; (2) session, meliputi: pembuatan site map/content map, pembuatan Information Design, pembuatan storyboard (jika perlu), pembuatan visual design setiap web page, pembuatan fitur multimedia dan flash (jika perlu), pengidentifikasian semua content material dengan lengkap (dari klien), pendokumentasian isu dan pertimbangan yang berkaitan dengan aplikasi web, dan penyimpulan sesi; (3) wrap Up, memberikan hasil berupa: penyelesaian dokumen JAD Design yang dihasilkan selama sesi, penyelesaian prototype berupa pembuatan link semua interface dalam web, peninjauan ulang dokumen dan prototype aplikasi web, dan presentasi kepada manajer dari klien mengenai rangkuman dari sesi JAD Design, tanggal development awal dan status proyek.

\section{Usulan Pengendalian Proyek}

Penggunaan Microsoft Project juga membantu dalam pembuatan laporan. Tool ini menyediakan fasilitas berupa report yang dapat menghasilkan laporan secara otomatis sehingga lebih hemat waktu. Fasilitas ini dapat diakses di Microsoft Project dengan memilih menu View - Report. Menu ini akan menampilkan beberapa jenis report yang dikelompokkan sesuai kebutuhan. Beberapa jenis laporan yang diusulkan adalah: (1) overview reports, terdiri dari: project summary, top level tasks, critical tasks, dan milestones; (2) current activity tasks, terdiri dari: unstarted tasks, tasks starting soon, task in progress, completed tasks, should have started tasks, dan slipping tasks; (3) assignment reports, terdiri dari: who does what, who does what when, dan to-do list.

\section{PENUTUP}

Berdasarkan penelitian yang dilakukan di Perusahaan pengembang perangkat lunak maka dapat disimpulkan bahwapPerusahaan pengembang perangkat lunak telah mengakomodasikan tujuh tahapan pengelolaan proyek perangkatlunak yang terdiri dari definition, analysis, design, programming, system test, acceptance, dan operation, ke dalam alur inisiasi penerimaan proyek dan lima tahapan yang terdiri dari requirement gathering/design, development, testing, deployment, dan warranty period. Lima tahapan ini diimplementasikan dalam Waterfall Model. Struktur organisasi tim proyek di perusahaan pengembang perangkat lunak tergolong organisasi matriks mengingat keterbatasan sumber daya manusianya. Penggunaan struktur organisasi matriks pada pembuatan proyek perangkat lunak dapat mengoptimalkan jadwal proyek. Perusahaan telah memanfaatkan metode Work Breakdown Structure (WBS) dan Microsoft Project sebagai tool dalam mengelola proyek perangkat lunak. Akan tetapi, tool ini belum dimanfaatkan untuk menentukan jalur kritis dari proyek. Hampir semua proyek yang ditangani oleh pengembang-pengembang pemula tersebut mengalami kemunduran dari rencana yang telah disusun.

Saran dalam pengelolaan proyek perangkat lunak adalah dengan penerapan Staged Delivery untuk dapat merencanakan tahapan proyek dengan lebih baik. Keunggulan model ini adalah tim 
proyek dapat menyerahkan fungsionalitas yang berguna kepada klien lebih awal tanpa harus menunggu sampai proyek selesai 100\%. Kemudian pemanfaatan Critical Path Method (CPM) diusulkan untuk mendukung estimasi penjadwalan proyek. Critical Path Method (CPM) adalah metodologi penjadwalan proyek untuk menentukan jadwal aktivitas yang optimal dengan memperhatikan waktu. Selanjutnya penerapan Joint Application Development (JAD) diusulkan untuk memperpendek tahapan pengumpulan kebutuhan user. Penerapan JAD dilakukan pada tahapan Requirement Gathering/Design untuk mengatasi seringnya terjadi perubahan kebutuhan user dan keterlambatan penyediaan content material dari klien. Dan terakhir diingatkan bahwa penerapan Staged Delivery, JAD serta CPM memerlukan dukungan dan komitmen dari kedua belah pihak baik pihak perusahaan pengembang perangkat lunak maupun klien agar dapat mencapai hasil terbaik dari masing-masing usulan tersebut.

\section{DAFTAR PUSTAKA}

McConnell, Steve. (1996). Rapid Development: Taming Wild Software Schedules. Washington: Microsoft Press.

Olson, David L. (2004). Introduction to Information Systems Project Management. New York: McGraw-Hill.

Project Management Institute. (2008). A Guide to the Project Management Body of Knowledge (4 ${ }^{\text {th }}$ ed.). Upper Darby: Project Management Institute.

Rakos, John J. (1990). Software Project Management: For Small to Medium Sized Projects. New Jersey: Prentice Hall.

Schwalbe, Kathy. (2010), Information Technology Project Management. Stamford: Course Technology, Cengage Learning

Shelford, Thomas J.; Remillard, Gregory A. (2003). Real Web Project Management: Case Studies and Best Practices from the Trenches. Boston: Addison-Wesley. 